\title{
Peran Ganda Suami Setelah Istri Menjadi Tenaga Kerja Wanita (TKW) dalam Keluarga: Studi Kasus di Kalijaga Lombok Timur
}

\author{
Sa'adah \\ Universitas Hamzanwadi \\ cacaraihan2205@gmail.com
}

\begin{abstract}
Abstrak
Tujuan penelitian ini adalah untuk mengetahui latar belakang perempuan menjadi TKW, untuk mengetahui peran ganda suami yang ditinggal istri pergi ke luar negeri, dan untuk mengetahui kehidupan sosial ekonomi keluarga perempuan yang pergi keluar negeri. Penelitian ini merupakan penelitian deskriptif kualitatif. Teknik pengumpulan data dilakukan dengan wawancara, observasi, studi pustaka dan dokumentasi. Teknik analisis yang digunakan adalah dengan reduksi data, penyajian data, dan penarikan kesimpulan. Hasil penilitian menunjukkan bahwa keputusan seorang istri menjadi seorang TKW memberikan dampak bagi seorang suami baik dari segi status maupun fungsi, serta perannya dalam keluarga. Beban pekerjaan yang ditanggung semakin bertambah berat terutama dalam mengurus pekerjaan rumah tangga dan mengurus kebutuhan anak, hal ini disebabkan karena suami hanya fokus bekerja mencari nafkah di luar rumah sedangkan untuk urusan pekerjaan rumah tangga dan mengurus kebutuhan biasanya dilakukan oleh istri. Adapun efek peran ganda suami adalah kurangnya waktu luang bersama anak dan masyarakat dalam melakukan kegiatan sosial masyarakat.
\end{abstract}

Kata Kunci: Peran Ganda, Suami, Tenaga Kerja Wanita

\begin{abstract}
The purpose of this study was to find out the background of women becoming TKW, to find out the dual role of husbands who left their wives to go abroad, and to find out the socio-economic life of women's families who went abroad. This research is a qualitative descriptive study. Data collection techniques were conducted by interview, observation, literature study and documentation. The analysis technique used is data reduction, data presentation, and drawing conclusions. The results of the study show that a wife's decision to become a migrant worker has an impact on a husband both in terms of status and function, as well as his role in the family. The workload that is borne is getting heavier, especially in taking care of household chores and taking care of children's needs, this is because the husband only focuses on working to earn a living outside the home while for household chores and taking care of needs is usually done by the wife. The effect of the husband's dual role is the lack of free time with children and the community in carrying out community social activities.
\end{abstract}

Keywords: Dual Role, Husband, Female Worker 


\section{Pendahuluan}

Keluarga merupakan bentuk lembaga yang paling utama dan kelompok primer yang terpenting dalam masyarakat. Keluarga juga merupakan susunan kelembagaan yang terbentuk atas dasar hubungan perkawinan yang sengaja dibentuk dan dipelihara. Keluarga adalah jiwa masyarakat dan tulang punggungnya. Kesejahteraan lahir dan batin yang dinikmati suatu bangsa, atau sebaliknya, kebodohan dan keterbelakangannya, adalah cerminan dari keadaan keluarga-keluarga yang hidup pada masyarakat bangsa tersebut (Shihab, 2014: 395). Perkawinan merupakan ikatan lahir batin antara pria dan wanita sebagai suami istri dengan tujuan membentuk keluarga atau rumah tangga yang bahagia dan kekal berdasarkan Ketuhanan Yang Maha Esa (Undang-undang Nomor 1 tahun 1974). Keluarga adalah unit terkecil dalam masyarakat yang terdiri dari suami istri atau suami istri dan anaknya (Undang-undang Nompr 23 Tahun 2002).

Biasanya dalam sebuah keluarga, ada peran-peran yang diletakkan pada para anggotanya, setiap anggota keluarga mempunyai hak dan kewajiban masing masing. Ayah yang merupakan pemimpin keluarga sangat berperan besar menjaga keutuhan keluarga, karena bertanggung jawab menafkahi anak dan ibunya. Tanggung jawab yang amat besar yang dipikul oleh ayah tentunya tidak bisa terlaksana apabila tidak ada dukungan dari anggota keluarga yang lainnya (Goode, 2004).

Selain dari ayah, peran ibu juga sangat penting dalam keluarga. Terutama tanggung jawab dalam mendidik anaknya. Selain dari menidik anak, ibu juga berperan aktif dalam mengurus segala keperluan rumah tangga. Tanggung jawab yang amat besar yang harus dilaksanakan oleh ibu tentunya sebuah proses dalam menjaga keutuhan keluarga. Kerjasama yang baik yang dilakukan oleh ayah dan ibu tentunya dapat menciptakan keluarga yang harmonis (Djamarah, 2004). Anak merupakan generasi penerus yang dapat meneruskan keturunan sebuah keluarga, tentunya harus mendapatkan perhatian penting terutama dari ayah dan ibunya. Ayah yang sejatinya bertugas mencari nafkah untuk memenuhi kebutuhan keluarganya sedangkan ibu bertugas untuk mengurus rumah serta mendidik anaknya. Pembagian tugas tersebut tidak lepas dari tanggung jawab keduanya dalam menjalin kejasama di dalam keluarga demi terselenggaranya rumah tangga yang sakinah yaitu keluarga yang sehat, dan bahagia, karena ibu yang mengatur, membuat rumah tangga menjadi surga bagi anggota keluarga, menjadi mitra sejajar yang saling menyayangi bagi suaminya. 
Berperannya perempuan disektor publik ternyata berdampak pada penghasilan tetap yang dapat digunakan untuk kebutuhan rumah tangga dan biaya pendidikan anak karena suami tidak memiliki pekerjaan tetap, maka posisi istri berganti menjadi pencari nafkah utama dalam keluarga sedangkan suami lebih banyak waktu dirumah. Peran istri sebagai pencari nafkah juga diperhitungkan. Untuk mencari tambahan nafkah bagi keluarga para istri harus mencari pekerjaan. Jumlah tenaga kerja selalu bertambah seiring dengan laju pertumbuhan penduduk yang semakin bertambah setiap tahunnya, namun hal ini tidak diikuti dengan penyerapan tenaga kerja yang memadai.

Rendahnya penyerapan tenaga kerja di dalam negeri dan kurangnya keterampilan terutama bagi wanita telah mendorong para pekerja wanita untuk mencari dan memanfaatkan kerja di luar negeri seperti Malaysia, Singapura bahkan sampai ke Arab Saudi dengan menjadi Tenaga Kerja Wanita (TKW). Suami mereka malah mengijinkan istrinya untuk bekerja ke luar negeri sebagai TKW. Ketika seorang istrimeninggalkan keluarga serta anak-anaknya, tentunya akanada pengalihan tanggung jawab antara suami dan istri. Selain itu, setiap anak mempunyai hak yang harus dipenuhi oleh kedua orang tuanya. Diantaranya hak untuk mendapatkan perlindungan, hak untuk hidup dan tumbuh kembang, hak untuk mendapatkan pendidikan, hak untuk mendapatkan nafkah dan waris serta hak untuk mendapatkan perlakuan yang sama.

Salah satu dampak dari keputusan istri yang memilih mejadi sorang TKW adalah bertambahnya peran suami dalam keluarga, dimana pekerjaan yang biasanya dikerjakan oleh istri mau tidak mau akan dikerjakan oleh suami seperti memasak, mencuci, mengurus segala kebutuhan anak dan lain sebagainya. Selain aktivitasnya didalam rumah, dampak lainnya juga akan berimbas pada kegiatan sosialnya bersama masyarakat seperti mengikuti pengajian, mengikuti kegiatan sosial bersama masyarakat, mengambil raport anak ke sekolah dan lain sebagainya.

Data pendahuluan yang diperoleh dari pemerintahan Desa Kalijaga, bahwa jumlah TKI pada tahun 2017 yang terdata oleh desa berjumlah 61 orang. Terdiri dari 44 orang laki-laki yang belum menikah dan 17 orang perempuan baik yang sudah menikah ataupun yang belum menikah (Profil Desa Kalijaga, 2018). Jumlah tesebut selalu meningkat setiap tahunnya. Data ini belum termasuk TKW yang tidak terdata oleh desa karena berangkat menjadi TKW secara sembunyi-sembunyi atau ilegal. 
Penelitian terdahulu yang relevan dengan penelitian ini di antaranya, penelitian Sosan (2010), kemudian adan penelitian Nawawi (2010), penelitian Jamiluddin (2017), penelitian Hunaifi (2017), kemudian ada penelitian Fatika (2018) yang secara umum membahas tentang perempuan sebagai pekerja migran di luar negeri. Perbedaan penelitian ini dengan beberapa penelitian di atas pada aspek peran laki-laki sebagai kepala keluarga yang ditinggal istri sebagai TKW. Oleh karena itu urgensi penelitian ini terletak pada peran ganda suami sebagai kepala keluarga ketika sang istri pergi bekerja sebagai TKW.

Berdasarkan permasalahan tersebut, peneliti melihat hal ini merupakan suatu pemandangan yang berbeda dari kehidupan keluarga TKW dibandingkan dengan kehidupan keluarga umumnya, sehingga peneliti merasa perlu meneliti lebih mendalam mengenai kehidupan keluarga TKW, terutama dalam memenuhi semua hak dan kebutuhan anaknya. Fokus penelitian ini adalah pada faktor penyebab istri menjadi seorang TKW, tingginya angka pengangguran di Desa Kalijaga, banyaknya laki-laki berperan ganda sebagai dampak dari istri yang menjadi TKW di Desa Kalijaga, dan terjadi perubahan peran ayah dalam keluarga sebagai akibat dariistri yang menjadi TKW. Adapun tujuan dalam penelitian ini adalah untuk mengetahui latar belakang perempuan menjadi TKW, mengetahui kehidupan sosial ekonomi keluarga perempuan yang pergi ke luar negeri, dan mengetahui peran ganda suami yang ditinggal istri pergi ke luar negeri.

\section{Metode Penelitian}

Penelitian ini merupakan penelitian deskriptif kualitatif (Sugiyono, 2010). Pengumpulan data yang digunakan dalam penelitian ini observasi, wawancara, dokumentasi, dan studi pustaka. Dalam penelitian ini yang diamati tentunya adalah kegiatan para suami TKW dalam melakukan aktifitas mengenai kehidupan ekonomi keluarga untuk memenuhi hak dan kebutuhan anak-anaknya. Seperti memberikan kenyamanan tempat tinggal, kebutuhan rumah tangga, serta pendidikan bagi anakanaknya. Wawancara digunakan untuk memperoleh informasi data dengan mengadakan tanya jawab. Dalam penelitian ini, yang digunakan adalah metode wawancara bebas terpimpin (Arikunto, 1998: 45). Hasil wawancara yang diperoleh berupa faktor yang mempengaruhi keputusan istri menjadi TKW. Dokumentasi yang digunakan sebagai penunjang penelitian penulis, dimana dalam dokumentasi ini dapat melihat, 
mengabadikan gambar dilokasi penelitian. Dokumentasi ini juga digunakan untuk mengumpulkan data-data yangberbentuk cacatan berupa hasil wawancara, dokumendokumen yang berkaitan dengan penelitian seperti foto-foto. Studi pustaka yaitu, suatu cara pengolahan data yang diambil dari berbagai literatur atau dari beberapa buku yang ditulis oleh para ahli, agar sesuai dan mendapatkan landasan teoretis atas masalah yang dikaji. Seperti buku, jurnal, serta sumber dari internet sebagai penunjang untuk melengkapi data yang di butuhkan. Teknik analisis data menggunakan model Miles dan Huberman yaitu, reduksi data, penyajian data, penarikan kesimpulan/verifikasi (Moleong, 2010).

\section{Pembahasan}

\section{Gambaran Umum Lokasi Penelitian}

Desa Kalijaga merupakan satu desa dari dua puluh empat Desa dalam Wilayah Kecamatan Aikmel Kabupaten Lombok Timur denagn Luas Wilayahnya +375, 230 Ha. yang meliputi 11 wilayah pedusunan dan terletak di bagian tengah dari wilayah Kecamatan Aikmel dengan Tofografis Daerah dataran rendah bukan pantai dengan ketinggian \pm 200 meter dari permukaan laut dan kemiringan $\pm 0-15 \%$. Suhu udara antara $\pm 23-30 \circ \mathrm{C}$ dengan tifologi desa adalah persawahan (daerah pertanian).

Orbitasi Desa Kalijaga dengan Desa-Desa tetangga sudah cukup lancar karna di dukung oleh sarana dan prasarana perhubungan yang memadai. Pembukaan jalan baru merupakan Alternatif untuk meningkatkan jangkauan perhubungan khususnya dengan wilayah Desa-desa yang baru di mekarkan dari Desa Induknya. Adapun orbitasi Desa Kalijaga dengan pusat-pusat pemerintahan Kecamatan, Kabupaten dan Provinsi yaitu; 1) Jarak Desa Kalijaga dengan Ibu kota Kecamatan Aikmel $\pm 1,5$ km; 2) Jarak Desa Kalijaga dengan Ibu Kota Kabupaten Lombok Timur \pm 15 km; 3) Jarak Desa Kalijaga dengan Ibu Kota Provinsi NTB \pm 55 km; 4) Jarak pusat Desa dengan Wilayah Dusun yag terjauh (Dasan Bongkot) \pm 200 m. Secara tofografi, Desa Kalijaga Kecamatan Aikmel, Kabupaten Lombok Timur merupakan daerah dataran tinggi di atas permukaan laut, curah hujan relatif rendah,

Struktur kelembagaan di Desa Kalijaga, disamping kelembagaan administratif Pemerintahan Desa, juga kelembagaan yang muncul atau yang di dorong keberadaannya dari motif ekonomi, budaya, kesehatan, pendidikan sosial politik. Kelembagaan dari 
pemerintah Desa antara lain, Pemerintah Desa, BPD, LKMD, PPK Desa, dari ekonomi, misalnya Bumdes, koperasi, kelompok usaha kecil, dan gabungan kelompok tani. Dari pendidikan seperti, komite sekolah. Dari kesehatan seperti posyandu. Dari sisi sosial dan Politik seperti karang taruna.

Struktur perekonomian Desa Kalijaga, Masih bercorak agraris yang menitik beratkan pada sektor pertanian. Hal ini di dukung oleh penggunaan lahan pertanian masih pempunyai porsi yang terbesar sebanyak $46,71 \%$ dari total penggunaan lahan desa. Mata pencaharian penduduk menggantungkan hidup pada sektor pertanian. Pada sektor ini komoditi yang menonjol sebagai hasil andalan adalah tanaman padi (Profil Desa Kalijaga, 2019). Beberapa sektor ekonomi yang tergolong economic base dan menonjol di smaping sektor pertanian adalah, perdagangan dan industri rumah tangga. Pada sektor perdagangan masyarakat Desa Kalijaga lebih banyak menumpukkan harapannya di pasar umum Aikmel dimana pasar tersebut jaraknya tidak terlalu jauh dari Desa Kalijaga. Pada sektor industri rumah tangga termasuk di dalamnya adalah kerajinan, jahit, bordir, dan pembuatan bata merah pembuatan Kerupuk, Genteng, pada sektor jasa, yang menonjol adalah tumbuhnya lembaga/institusi keuangan micro berupa koperasi sebagai pendudukung ekonomi Desa. Hal ini diharapkan akanmembawa dampak positif dalam perkembangan ekonomi Desa Kalijaga secara keseluruhan.

Mata pencaharian penduduk Desa Kalijaga adalah Mayoritas sebagai petani dan buruh, namun tidak memungkinkan bahwa kondisi ekonomi masyarakat Desa Kalijaga dikatakan minim. Bahkan bisa dikatakan bahwa kondisi ekonomi masyarakat desa Kalijaga sudah berkembang dilihat dari banyaknya para pedagang dan peternak yang merupakan mata pencaharian yang dijadikan sebagai usaha. Mendirikan industri kecil menengah dengan mengolah bahan mentah menjadi bahan jadi dan barang yang dinilainya lebih tinggi. Dilihat dari kondisi pendidikan, masyarakat desa Kalijaga sudah maju dimana dilihat dari mata pencahariannya sebagai PNS, TNI, dan Guru (Profil Desa Kalijaga tahun 2019).

Pendidikan merupakan salah satu sektor penting bagi kehidupan, sebab faktor pendidikan merupakan berometer penetu tingakat kemajuan suatu daerah. Sementara maju atau mundurnya pendidikan dan sarana prasarana yang menunjangnya seperti gedung, dukungan dan animo masyarakat untuk memanjukan pendidikan itu sendiri. Lembaga-lembaga pendidikan yang ada di Desa Kalijaga adalah Pendidikan Anak Usia 
Dini (PAUD) 1 buah, Taman Kanak-Kanak 9 buah, SD/MI 5 buah, SLTP/MTS 6 buah, SLTA/SMA/SMK 4 buah. Selain fasilitas pendidikan tersedia juga pasilitas kesehatan berupa 2 puskesmas, dan 1 polindes dengan seorang bidan Desa. Selain itu tesedia sarana dan prasarana penunjang kesehatan lain berupa sarana posyandu yang tersedia pada setiap dusun yang berada di Desa.

\section{Latar Belakang Perempuan Menjadi TKW di Desa Kalijaga Lombok Timur}

Tenaga Kerja Wanita adalah (TKW) setiap wanita yang mampu melakukan pekerjaan, baik di dalam maupun di luar hubungan kerja, guna menghasilkan sesuatu yang berupa barang atau jasa untuk memenuhi kebutuhan masyarakat. Dalam penelitian ini, TKW merupakan tenaga kerja Indonesia (TKI) yang bekerja di luar negeri. Peran perempuan dalam ekonomi rumah tangga semakin penting sejalan dengan menurunnya peranan sektor pertanian dalam perekonomian desa sehingga tak jarang dengan kondisi tersebut memaksa mereka membantu suami dengan bekerja diluar rumah bahkan menjadi TKW di luar negeri untuk menopang hidup bersama keluarga mereka, sehingga tentunya berdampak pada kehidupan keluarga yang ditinggalkan yaitu suami dan anaknya. Adapun Negara tujuannya beragam diantaranya Malaysia, Arab Saudi, Taiwan, dan Qatar.

Berdasarkan data yang diterima dari pemerintah desa Desa Kalijaga bahwa sampai tahun 2019 ini ada sebanyak 26 perempuan yang memilih menjadi TKW ke luar negeriyang notabenenya sudah berkeluarga yaitu sebanyak 8 orang single parent dan 18 orang yang masih bersuami dan memiliki anak. Karena penelitian ini tentang peran ganda suami TKW maka yang menjadi informan dalam penelitian ini adalah suami yang istrinya menjadi TKW yaitu sebanyak 18 orang suami (Profil Desa Kalijaga, 2019).

Umumnya perempuan di Desa Kalijaga memilih menjadi TKW dikarenakan beberapa faktor. Pertama, tekanan ekonomi. Kedua, lingkungan keluarga yang sangat mendukung dalam bekerja. Ketiga, tidak ada peluang kerja lain sesuai dengan ketrampilannya. Hal tersebut senada dengan yang dikatakan oleh Sohri selaku Kepala Desa di Desa Kalijaga:

Adapun yang melatarbelakangi perempuan di desa Kalijaga memilih menjadi TKW adalah karena faktor ekonomi keluarga, dimana suaminya tidak bekerja ataupun tidak memiliki penghasilan yang tetap sehingga tidak mampu mencukupi kebutuhan keluarganya sehari-hari, selain itu karena minimnya peluang kerja yang sesuai dengan keterampilan yang dimiliki, sehingga mereka memilih menjadi TKW 
dengan harapan mampu memperbaiki ekonomi keluarga (Wawancara, 10 Mei 2019).

Terkait faktor yang melatar belakangi perempuan yang menjadi TKW, pernyataan yang sama juga disampaikan oleh beberapa suami dari TKW salah satunya adalah Ridwan yang ditinggal istrinya sejak 1 tahun 2 bulan dan memiliki 3 orang anak mengatakan:

Saya mengizinkan istri saya menjadi TKW dengan alasan kondisi ekonomi keluarga kami yang tidak baik karena kalau hanya mengandalkan penghasilan saya sebagai tukang ojek tentu tidak mampu mencukupi kebutuhan keluaga yang semakin hari semakin bertambah seiring dengan tumbuh kembangnya anak-anak kami (Wawancara, 14 Mei 2019).

Selanjutnya Muhammad mengatakan bahwa istri saya terpaksa menjadi TKW untuk membantu kebutuhan keluarga karena saya tidak lulus kesehatan untuk menjadi seorang TKI sehingga selama ini saya hanya menjadi buruh tani (Wawancara, 14 Mei 2019). Kemudian Marzoan salah satu suami yang istrinya mejadi TKW sejak dua (2) tahun yang lalu dan memiliki 4 orang anak mengakui bahwa:

Saya mengizinkan istri saya menjadi TKW karena kondisi ekonomi keluarga kami yang tidak baik, dimana sejak 6 tahun terakhir ini saya sudah tidak bisa bekerja lagi seperti biasanya dikarenakan kesehatan saya yang menurun sejak mengidap penyakit usus yang saya derita selama ini (Wawancara, 13 Mei 2019).

Alasan lainnya juga dikemukan oleh 6 orang suami TKW yaitu, Muslih dan Nurdin yaitu untuk memenuhi keinginan anak mereka untuk melanjutkan pendidikan atau kuliyah. Nurdin mengatakan bahwa Istri saya pergi menjadi TKW karena ingin mewujudkan cita-cita anak mereka yang ingin kuliyah, karena jika hanya mengandalkan penghasilan saya sebagai kuli bangunan tentu tidak akan cukup (Wawancara, 15 Mei 2019). Namun pernyataan berbeda diungkapkan oleh 2 orang suami salah satunya adalah Fahmi seoarang suami yang istrinya menjadi TKW sejak satu setahun yang lalu dan memiliki 1 (satu) orang anak. Saya dengan terpaksa membiarkan istri saya pergi menjadi TKW atas keinginannya sendiri karena tergiur melihat keberhasilan kerabatnya yang sudah menjadi TKW sejak beberapa tahun yang lalu (Wawancara, 20 Mei 2019).

Terlepas dari beberapa faktor yang melatar belakangi seorang istri menjadi TKW tentu ada persepsi-persepsi yang muncul dari orang-orang disekitarnya seperti suami, keluarga dan kerabat serta tetangga disekitarnya. Terkait hal tersebut saat ditanya mengenai persepsinya terhadap keputusan istrinya menjadi TKW rata-rata menjawab 
tidak masalah selama istrinya bekerja dengan baik serta menjaga kepercayaan yang sudah diberikan. Dituturkan oleh Saleh yang ditinggal istrinya sejak 2 tahun lalu. Saya tidak ada masalah dengan keputusan istri saya menjadi TKW asalkan disana dia mengerjakan pekerjaan yang baik dan menjaga kepercayaan yang sudah kami berikan padanya, toh juga dia bekerja untuk kami dan keluarga (Wawancara, 15 Mei 2019).

Begitupun persepsi yang muncul dari keluarga dan kerabat serta tetangga mereka yang rata-rata merespon positif, salah satu yang dituturkan oleh ibu Salmin kerabat dari istrinya Muslih yang mengatakan bahwa saya sih mendukung saja kalau anak saya menjadi TKW yang penting dia diizinkan suaminya dan itu sudah menjadi urusan rumah tangga mereka, dan kamipun tidak bisa berbuat apa-apa karena kehidupan kamipun juga susah jadi kita sama-sama susah (Wawancara, 15 Mei 2019). Senada dengan apa yang dikatakan Umi Aisyah bahwa saya salut melihat istri-istri yang mau kerja ke luar negeri untuk membatu suaminya dalam memenuhi kebutuhan keluarga daripada mereka diam dirumah dan menambah beban hidup keluarga mereka, semoga saja mereka berhasil disana supaya kehidupan ekonominya berubah menjadi lebih baik (Wawancara, 13 Mei 2019).

Jadi berdasarkan beberapa paparan dari hasil wawancara diatas bahwa ada beberapa faktor yang melatar belakangi perempuan (istri) memilih menjadi seorang TKW dan persepsi yang muncul dan dialami oleh beberapa informan dalam penelitian ini antara lain:

a. Tekanan kebutuhan ekonomi keluarga yang sewajarnya menjadi tanggung jawab seorang suami dalam memenuhi kebutuhan ekonomi keluarga. Namun karena kondisi suami yang tidak bekerja atau tidak memiliki penghasilan yang tetap bahkan karena kondisi kesehatan suami yang kurang sehat dan tidak bisa untuk melakukan pekerjaan yang berat sementara kebutuhan hidup yang terus bertambah, hal itu dirasakan amat berat bagi pasangan suami istri yang memiliki tanggung jawab lebih yaitu kelansungan hidup anak-anak mereka. Sehingga untuk menyelesaikan masalah itu, istri memilih menjadi seorang TKW dengan harapan bisa merubah kehidupan ekonomi keluarga menjadi lebih baik.

b. Minimnya lapangan pekerjaan bagi perempuan yang ingin bekerja untuk membantu suami dalam menopang kebutuhan hidup sehari-hari membuat perempuan memilih 
menjadi seoarang TKW.Hal ini dirsakan oleh semua informan yaitu sebanyak 18 responden.

c. Meningkatnya gengsi sosial karena melihat keberhasilan kerabat dan orang disekitarnya dalam memperbaiki kehidupan sosialnya dengan menjadi TKW juga memicu perempuan untuk memilih bekerja ke luar negeri menjadi seorang TKW.

d. Adanya tanggung jawab terhadap kalangsungan pendidikan anak sehingga untuk mewujudkan cita-cita anaknya untuk sekolah tinggi dengan harapan agar kelak kehidupan anaknya jauh lebih baik dari kehidupannya yang sekarang juga sebagai dorongan semangat sekaligus alasan istri memilih bekerja membantu ekonomi keluarga dengan menjadi TKW.

e. Persepsi yang muncul dari orang-orang di sekitarnya seperti suami, keluarga dan kerabat serta tetangga disekitarnya mengenai keputusan istrinya menjadi TKW ratarata menjawab positif dan cenderung mendukung karena diizinkan oleh suaminya dan tidak ikut campur karena itu sudah menjadi urusan rumah tangga mereka.

\section{Peran Ganda Suami dalam Keluarga}

Keputusan perempuan (istri) menjadi TKW tentunya memiliki dampak yang dirasakan oleh pasangan atau keluarga yang terutama bagi anak dan ibu. Salah satu dampak yang dirasakan oleh suami adalah terjadinya perubahan peran atau peran ganda seorang suami dalam keluarga. Seiringdengan terjadinya perubahan peran dan fungsi seorang suami, benturan ekonomi, statussosialserta semakin bertambahnya urusan rumah tangga membuat suami dituntut untuk bekerja sekaligus mengurus kebutuhan rumah tangga. Perannya untuk menjadi kepala keluarga tetap dijalankan dalam kesehariannya yaitu memegang peranan penting sebagai ayah sekaligus sebagai ibu dalam keluarga. Suami yang ditinggalkan istrinya dengan penyesuaian diri yang baik maka akan mampu mengurus dan membesarkan anak-anak sendirian.

\section{Mengurus Pekerjaan Rumah}

Sebagai suami yang ditinggal istrinya menjadi TKW tentu akan menambah peran suami dalam keluarga yaitu sebagai kepala keluarga sekaligus sebagai ibu bagi anakanaknya sehingga mau tidak mau selain bekerja diluar rumah suami juga dituntut untuk bisa mengurus pekerjaan rumah tangga. Terkait hal tersebut beberapa ulasan wawancara bersama informan salah satunya Muhammad menuturkan bahwa setelah istri saya 
menjadi TKW, saya merasa sedikit terbebani dengan urusan pekerjaan rumah karena biasanya saya hanya kerja diluar sementara untuk urusan rumah tangga dikerjakan sama istri saya (Wawancara, 14 Mei 2019). Pernyataan yang sama juga diungkapkan oleh Yahya yang mengatakan bahwa untuk urusan pekerjaan rumah tangga saya merasa sangat kualahan karena saya juga harus kerja mencari rezeki diluar, jadi saya sebisa mungkin untuk membagi waktu (Wawancara, 15 Mei 2019).

Namun penyataan berbeda juga diungkapkan oleh oleh Nurdin yang mengatakan bahwa untuk urusan pekerjaan rumah saya berbagi tugas dengan anak-anak saya dengan membuat jadwal karena anak-anak saya sudah cukup besar (Wawancara, 15 Mei 2019). Kemudian ada informan yang mengungkapkan pernyataan lain salah satunya Herman yang meminta bantuan keluarganya dalam mengurus rumah dan anak-anaknya. Karena anak-anak saya masi kecil-kecil jadi untuk urusan pekerjaan rumah saya minta bantuan keluarga dan kerabat selagi saya sedang bekerja diluar rumah (Wawancara, 15 Mei 2019)

\section{Mengurus Keperluan Anak}

Selain urusan pekerjaan rumah tangga, hal yang tak kalah pentingnya adalah urusan kebutuhan anak. Sebagai seorang suami yang ditinggal istrinya yang berperan sebagai kepala keluarga yang memiliki tanggung jawab terhadap keluarga dengan bekerja dan mengurus segala urusan rumah tangga termasuk mengurus keperluan anak-anak seperti keperluan pendidikan, belanja, dan lain sebagainya. Hal ini menunjukkan pentingnya peran ayah didalam keluarga dengan tidak hadirnya seorang ibu. Dalam hal mengurus keperluan anak beberapa pernyatan diungkapkan oleh informan antara lain:

Terkait hal mengurus keperluan anak rata-rata informan tidak mengalami kendala apapun dalam memenuhi kebutuhan anak-anaknya hanya saja mereka tidak bisa sepenuhnya menemani anak-anak mereka karena sering terbentur dengan pekerjaannya, sebagaimana yang ditutur oleh beberapa informan diantarannya Ramli yang mengatakan bahwa aya tidak merasa kewalan dalam mengurus keperluan anak-anak saya karena anak-anak saya sudah besar dan bisa mengurus diri mereka sendiri saya hanya menyiapkan kebutuhannya saja (Wawancara, 16 Mei 2019).

Hal senada juga dituturkan oleh Jamal yang memiliki 2 orang anak bahwa untuk kebutuhan anak saya mulai dari makanan dan biaya pendidikannya saya siapkan sebelum berangkat kerja, dan jika ada kebutuhan yang dibutuhkan biasanya anak saya mengasih tau ketika saya berada dirumah (Wawancara, 15 Mei 2019). Selain menyiapkan kebutuhan anak-anaknya para suami juga sering meluangkan waktunya untuk berkumpul 
bersama anak-anak mereka sepulang kerja atau waktu santai dan makan malam. Hal ini dituturkan oleh beberapa informan seperti, Nurdin yang menuturkan bahwa ketika saya sedang berada di rumah sebisa mungkin saya dan anak-anak kumpul untuk sekedar ngobrol bareng tentang masalah-masalah yang dihadapi anak-anak di sekolah maupun di rumah, hal ini biasa kami lakukan pada waktu makan malam atau sesudahnya (Wawancara, 15 Mei 2019).

Dari beberapa tuturan diatas dapat disimpulkan bahwa jika para suami memiliki waktu luang disela rutinitas perjaannya sebisa mungkin mereka meluangkan waktu untuk berkumpul bersama anak-anak mereka walaupun Cuma sekedar makan bareng ataupun ngobrol sambil nonton tv, menanyakan kegiatan anak-anak nya baik di sekolah maupun dirumah waktu ayah mereka sedang bekerja di luar rumah, Lain halnya dengan Herman yang memilih menikah lagi agar ada yang mengurus kebutuhannya dan anak-anaknya. Sebagai laki-laki normal tentu saya menginginkan adanya seorang istri di rumah untuk mengurus kebutuhan saya dan anak-anak saya dirumah selagi saya sedang bekerja" (Wawancara, 21 Mei 2019). Pernyataan lain juga diungkapkan oleh Zulfikar yang memilih kawin lagi dan menitipkan anak-anaknya pada saudaranya. Setelah istri saya pergi ke luar negeri sebagai TKW, saya menitipkan anak-anak saya sama saudara saya karena saya kawin lagi dan anak-anak tidak mau tinggal bersama saya dan ibu tiri mereka (Wawancara, 20 Mei 2019).

Meski menjadi kepala keluarga dan orang tua tunggal terbilang tidak mudah untuk dijalani, namun para suami yang istrinnya menjadi TKW yang ada di Desa Kalijaga tetap dapat menjalani perannya sebagai orangtua tunggal sekaligus kepala keluarga. Mereka bekerja mencari nafkah untuk memenuhi kebutuhan hidup keluarganya, selain itu mereka tidak hanya berperan dalam sektor publik tetapi juga disektor domestik dimana mereka akan mendapat penghargaan dalam masyarakat serta dapat mengembangkan bakat, potensi dan kemampuan yang dimiliki sebagai aktualisasi diri. Hal ini diungkapkan oleh Nurdinsalah satu suami yang ditinggal istrinya menjadi TKW sejak dua (2) tahun lalu dan memiliki tiga orang anak:

Sebagai orang tua tunggal saya harus bekerja untuk memenuhi kebutuhan keluarga dan mengurus rumah tangga serta anak-anak saya namun tidak menyepelekan aktivitas sosial bersama masyakat disekitar saya seperti ikut gotong royong dan aktivitas sosial lainnya bersama masyakat (Wawancara, 20 Mei 2019). 
Selanjutnya Adnan dan beberapa suami lainnya lebih memilih menjadi buruh tani dan kuli bangunan untuk mencukupi kebutuhan hidupnya dan anaknya dan mengurus rumah tangga bersama anak- anaknya, sedangkan Yahya dan beberapa suami lainnya memilih bekerja wiraswasta atau dengan berdagang dan dibantu oleh anak-anaknya. Meskipun istri saya bekerja menjadi TKW, saya tetap bertanggung jawab memberikan nafkah bagi anak-anak saya dengan bekerja seperti biasanya yaitu menjadi buruh tani (Wawancara, 20 Mei 2019). Taufik juga menuturkan demikian bahwa dia tetap menjalani profesinya sebagai kuli bangunan mengatakan bahwa untuk memenuhi kebutuhan rumah tangga dan anak-anak saya, saya tetap bekerja seperti biasanya meskipun istri saya bekerja mencari uang dengan menjadi TKW (Wawancara, 20 Mei 2019).

Jadi berdasarkan beberapa paparan dari hasil wawancara terkait dengan peran ganda suami TKW di atas dapat disimpulkan bahwa:

a. Tugas mengurus pekerjaan rumah dirasakan cukup berat, namun tetap dilakoni oleh suami karena sebelumnya masalah pekerjaan rumah biasa dilakukan oleh istri-istri mereka. Selain mengurus sendiri ada juga beberapa informan yang berbagi tugas dengan anak-anak mereka dalam mengurus pekerjaan rumah tangga, tetapi ada juga yang minta batuan keluarga atau kerabatnya dalam membantu mengurus rumah tangga.

b. Dalam hal mengurus kebutuhan anak, rata-rata informan menyiapkan kebutuhan anaknya seperti uang sakudan biaya pendidikan anaka- anaknya. Sebagian besar informan juaga sebisa mungkin meluangkan waktu untuk berkumpul bersama anakanaknya walau hanya sekedar makan, ngobrol santai ataupun membantu anaknya mengerjakan tugas sekolahnya.

c. Meskipun istri mereka bekerja menjadi TKW, para suami tetap bertanggungjawab akan kewajibannya sebagai kepala rumah tangga yaitu menafkahi keluarga dengan tetap melakoni pekerjaannya sebagaimana biasanya.

Adapun efek dari peran ganda yang disandang oleh seorang suami TKW antara lain:

a. Kurangnya waktu luang bersama-sama anak-anak seperti mengantar anak ke sekolah, mengikuti rapat wali murid, dan lain-lain.

b. Anak menjadi korban yang mestinya melakukan kegiatan seperti teman- teman seusianya terpaksa harus berbagi waktu untuk membantu orangtuanya mengurus rumah tangga. 
c. Kurang nya waktu untuk bersosial bersama masyarakat seperti gotong royong, mengikuti pengajian, musyawarah kampong, dan lain sebagainya karena terkadang berbenturan dengan jadwal kerja di rumah atau pun di luar rumah.

Ketika seorang istrimeninggalkan keluarga serta anak-anaknya, tentunya akanada pengalihan tanggung jawab antara suami dan istri. Selain itu, setiap anak mempunyai hak yang harus dipenuhi oleh kedua orang tuanya. Di antaranya hak untuk mendapatkan perlindungan, hak untuk hidup dan tumbuh kembang, hak untuk mendapatkan pendidikan, hak untuk mendapatkan nafkah dan waris serta hak untuk mendapatkan perlakuan yang sama. Mengingat seorang ibu ketika menjadi TKW akan meninggalkan keluarganya kurang lebih tiga tahun lamanya. Hal tersebut menyebabkan hak anak akan dipenuhi oleh ayahnya. Sedangkan seorang ayah tentunya minim akan pengalaman untuk mengurus rumah tangga serta anaknya. karena, pada umumnya seorang ayah bertugas untuk memberikan nafkah kepada keluarganya. Salah satu dampak dari keputusan istri yang memilih mejadi sorang TKW adalah bertambahnya peran suami dalam keluarga, dimana pekerjaan yang biasanya dikerjakan oleh istri mau tidak mau akan dikerjakan oleh suami seperti memasak, mencuci, mengurus segala kebutuhan anak dan lain sebagainya. Selain aktivitasnya dalam rumah, dampak lainnya juga akan berimbas pada kegiatan sosialnya bersama masyarakat seperti mengikuti pengajian, mengikuti kegiatan sosial bersama masyarakat, mengambil raport anak ke sekolah dan lain sebagainya.

Menjadi orang tua tunggal bagi sebagian besar masyarakat memanglah tidak mudah meskipun dia adalah seorang laki-laki, namun apabila diberi dorongan dan motivasi para suami mampu menyesuaikan dirinya dengan keadaan sebagai ayah sekaligus ibu bagi anak-anaknya. Penyesuaian diri merupakan suatu proses dinamis yang bertujuan mengubah perilaku individu agar terjadi hubungan yang lebih sesuai antara diri individu dengan lingkungansosialnya. Penyesuaian diri menunjuk pada keberhasilan individu memainkan peranannya untuk mengadakan hubungan dengan orang lain atau keluarga dan memperlihatkan sikap, serta tingkah laku yang menyenangkan (Fathurrohman, dkk. 2013; Koesoema, 2007). Penyesuaian diri yang berhasil akan menunjuk pada kondisi mental seorang ayah yang stabil dalam artimampu menyelesaikan masalahnya secara realistis. Telah banyak pula suami tanpa istri yang berhasil dalam mendidik anak-anaknya dimana mereka tetap dapat berkecimpung dalam hidup bermasyarakat dan mengajarkan 
bahwa kehidupan tanpa ibu harus tetap berjalan dengan baik. Dengan menjalankan peran kerumahtanggaan secara profesional dan menjalankan peran ganda sebagai ayah sekaligus ibu dalam menjalankan peran dalam rumahtangga sekaligus mencari penghasilan bagi anak-anaknya serta mengurus urusan rumahtangga adalah suatu kebanggaan dan kehormatan, dimana ayah dapat berkontribusi ke dalam rumah dan berkontribusi di luar rumah secara optimal.

Sebagai orang tua tunggal sekaligus sebagai kepala keluarga, seorang ayah tidak hanya bertanggung jawab dalam hal materi dengan bekerja untuk kebutuhan sehariharinya saja namun ada juga hal penting yang harus diperhatikan oleh ayah sebagai orang tua tunggal sekaligus sebagai kepala keluarga yaitu perkembangan dan pertumbuhan anak-anaknya mulai dari segi pendidikan anak-anaknya serta kegiatan sosialnya bersama masyarakat (Kurniawan, 2013; Lestari, 2013).

Dari hasil penelitian mengenai alasan seorang istri menjadi TKW disebabkan oleh beberapa faktor yang dialami oleh beberapa informan diantaranya tekanan kebutuhan ekonomi keluarga yang sewajarnya menjadi tanggung jawab seorang suami dalam memenuhi kebutuhan ekonomi keluarga. Namun karena kondisi suami yang tidak bekerja atau tidak memiliki penghasilan yang tetap. Minimnya lapangan pekerjaan bagi perempuan yang ingin bekerja untuk membantu suami dalam menopang kebutuhan hidup sehari-hari juga menjadi alasan membuat perempuan memilih menjadi seoarang TKW. Selanjut faktor lingkungan dimana keberhasilan kerabat dan orang di sekitarnya dalam memperbaiki kehidupan sosialnya dengan menjadi TKW juga memicu perempuan untuk memilih bekerja ke luar negeri menjadi seorang TKW.

Selanjutnya peran ganda yang disandang oleh seoarang suami dimana selain berperan sebagai ayah dia juga harus berperan sebagai seorang ibu. Bertambahnya peran suami dalam keluarga, dimana pekerjaan yang biasanya dikerjakan oleh istri mau tidak mau akan dikerjakan oleh suami seperti, memasak, mencuci, mengurus segala kebutuhan anak dan lain-lain. Hal ini dirasa sangatlah berat sebagaimana yang dirasakan oleh masyarakat. Hal ini disebabkan karena biasanya suami hanya fokus kerja di luar rumah mencari nafkah dimana pekerjaan rumah biasanya dikerjakan oleh istri. Beberapa masyarakat lainnya lebih memilih minta bantuan keluarga dan kerabatnya untuk mengurus pekerjaan rumah bahkan ada yang memilih menikah lagi. 
Selanjutnya sebagai orang tunggal yang memiliki anak tentu tak terlepas dari tanggungjawabnya terhadap kebutuhan dan perkembangan serta pendidikan anak-anakya dengan cara meluangkan waktu untuk sekedar ngobrol ataupun mendampingi anak mengerjakan tugas sekolahnya. Hal ini sering dilakukan oleh beberapa masyarakat lainnya yang memilih menitipkan anaknya pada kerabatnya. Selain masalah beban yang tanggung dalam keluarga, sebagai keluarga yang tidak utuh seperti keluarga pada lazimnya tentu akan berimbas pada psikologis anak-anaknya. Anak-anak bisa menjadi korban perpisahan orang tuanya meskipun hanya sementara waktu, serta berimbas pada kegiatan sosialnya bersama masyarakat seperti gotong royong, pengajian, musyawarah kampung, dan kegiatan lainnya.

\section{Kesimpulan}

Keadaan ekonomi keluarga serta minimnya lapangan pekerjaan adalah hal yang melatarbelakangi perempuan atau istri memutuskan menjadi TKW. Keputusan seorang istri menjadi seorang TKW memberikan dampak bagi bagi kehidupan sosial ekonomi keluarga yang ditinggalkan terutama bagi seorang suami baik dari segi status maupun fungsi, dan perannya dalam keluarga. Beban pekerjaan yang ditanggung suami semakin bertambah berat terutama dalam mengurus pekerjaan rumah tangga dan mengurus kebutuhan anak, hal ini disebabkan karena sebelumnya suami hanya fokus berkerja mencari nafkah diluar rumah sedangkan untuk urusan pekerjaan rumah tangga dan mengurus kebutuhan biasanya dilakukan oleh istri.

\section{Daftar Rujukan}

Arikunto, S. (1998). Prosedur Penelitian Suatu Pendekatan Praktek. Cetakan ke-11. Jakarta: PT Rineka Cipta.

Djamarah, Syaiful Bahri. (2004). Pola Komunikasi Orang TuadanAnak dalam Keluarga Sebuah Perspektif Pendidikan Islam. Jakarta: Rineka Cipta.

Fathurrohman, Pupuh H., AA Suryana, dan Fenny Fatriany. (2013). Pengembangan Pendidikan Karakter. Bandung: Refika Aditama.

Fatika, B. D. A. (2018). Pergaulan Anak Yang Orangtua Sebagai Tenaga Kerja Indonesia (TKI) (Kasus di Desa Gelogor Kecamatan Kediri Kabupaten Lombok Barat), Skripsi, Mataram: Universitas Mataram.

Goode, Wiilam J. (2004). Sosiologi Keluarga. Jakarta: Bumi Aksara.

Hunaifi, H. (2017). Pandangan Tuan Guru Terhadap Pembagian Kerja Bagi IstriYang Bekerja Sebagai TKW (Studi Di Desa Kediri Lombok Barat). Al-IHKAM: Jurnal 
Hukum Keluarga Jurusan Ahwal al-Syakhshiyyah Fakultas Syariah IAIN Mataram, 9(01), 134-150.

Jamiluddin, J. (2017). Problem Pendidikan Anak Tenaga Kerja Wanita Indonesia (TKWI) di Desa Keruak Kecamatan Keruak Kabupaten Lombok Timur. FONDATIA, 1(1), 17-28.

Koesoema, Doni. 2007. Pendidikan Karakter Strategi Mendidik Anak di Zaman Global. Jakarta: Grasindo.

Kurniawan, Syamsul. 2013. Pendidikan Karakter. Yogyakarta: Ar-Ruzz Media.

Lestari, D. Y. (2013). Pembinaan karakter siswa di SMP Nasional Pati. DEMOCRATIA, $1(2)$.

Moleong, Lexy J. (2010). Metodologi Penelitian Kualitatif. Bandung: PT. Remaja Rosdakarya.

Nawawi, M. A. (2010). Pergeseran Peran dan Fungsi Suami Terhadap Pendidikan Anak Dalam Keluarga Tenaga Kerja Wanita (TKW) di Luar Negeri (Studi Kasus Desa Penujak Kecamatan Praya Barat Kabupaten Lombok Tengah, Skripsi, Mataram: Universitas Mataram.

Profil Desa Kalijaga Tahun 2019.

Shihab, M. Quraish. (2014). Menabur Pesan Ilahiyah, Jakarta: Lentera Hati.

Sosan, I. (2010). Peran ganda ibu rumah tangga yang bekerja sebagai tukang amplas kerajinan ukir kayu. Komunitas: International Journal of Indonesian Society and Culture, 2(2).

Sugiyono. 2010. Metode Penelitian Pendekatan Kuantitatif. Kualitatif. R \& D. Bandung: Alfabeta.

Undang-undang Nomor 23 Tahun 2002 tentang Perlindungan Anak.

Wawancara, Fahmi, 20 Mei 2019.

Wawancara, Herman, 15 dan 21 Mei 2019.

Wawancara, Jamal, 15 Mei 2019.

Wawancara, Marzoan, 13 Mei 2019.

Wawancara, Muhammad, 14 Mei 2019.

Wawancara, Muslih, 15 Mei 2019.

Wawancara, Nurdin, 15 dan 20 Mei 2019.

Wawancara, Ridwan, 14 Mei 2019.

Wawancara, Sohri, 10 Mei 2019.

Wawancara, Taufik, Mei 2019.

Wawancara, Yahya, 15 dan 20 Mei 2019.

Wawancara, Zulfikar, Mei 2019.

Wawancara, Umi Aisyah, 13 Mei 2019. 